\title{
Identification of Arable Marginal Lands under Rainfed Conditions for Bioenergy Purposes in Spain
}

\author{
Carlos S. Ciria ${ }^{1,2, *(D)}$, Marina Sanz ${ }^{1}$, Juan Carrasco ${ }^{1}$ and Pilar Ciria ${ }^{1}(\mathbb{D}$ \\ 1 CEDER-CIEMAT-Centro de Desarrollo de Energías Renovables, Autovía de Navarra A-15, Salida 56, \\ 42290 Soria, Spain; marina.sanz@ciemat.es (M.S.); juan.carrasco@ciemat.es (J.C.); pilar.ciria@ciemat.es (P.C.) \\ 2 Departamento de Producción Agraria, Universidad Politécnica de Madrid (UPM), 28040 Madrid, Spain \\ * Correspondence: carlossixto.ciria@ciemat.es; Tel.: +34-975-281-013
}

Received: 1 March 2019; Accepted: 22 March 2019; Published: 27 March 2019

\begin{abstract}
The cultivation of bioenergy crops could be considered as sustainable; however, its use in fertile lands could conflict with food production. The general purpose of this study is to identify areas where traditional food crops are not economically sustainable, but where they could be substituted by energy crops without changing the land use in Spain. We studied the profit margin of the main crops of the country, which are wheat (Triticum aestivum L.) and barley (Hordeum vulgare L.), the spatial location of the growing areas, and the biophysical constraints. Spain has an extended area of 9.93 million hectares, with biophysical and/or economic constraints in rainfed arable areas. Grain yields $\leq 1.5 \mathrm{Mg} \mathrm{ha}^{-1}$ are not profitable; low organic matter content is the principal biophysical constraint. The average results showed a potential of $83.33 \mathrm{GJ} \mathrm{ha}^{-1}$ using triticale ( $x$ Triticosecale) and $174.85 \mathrm{GJ} \mathrm{ha}^{-1}$ using cardoon (Cynara cardunculus L.) in arable marginal lands. The production of biomass in this area would serve to cover between 3\%-5\% of primary energy needs in Spain for triticale or cardoon. In this respect, establishing energy crops in marginal lands could be an instrument to enhance rural development, boost the bio-economy, and reach environmental targets.
\end{abstract}

Keywords: rainfed agriculture; herbaceous crops; economic constraints; biophysical constraints; biomass

\section{Introduction}

Agriculture currently faces multiple challenges. On one hand, more food and fiber need to be produced to feed a growing population [1], and, on the other, more feedstock is needed for potentially huge bioenergy and bio-based products markets. Considering that the biomass available residues pose limited energy potential, crops specifically grown for lignocellulosic biomass production could provide a secure, sustainable, and autochthonous feedstock for a future de-carbonized heat and electricity production $[2,3]$. Therefore, in addition to adapting to climate change, the agricultural sector has to adopt more efficient and sustainable production methods to cover the increased and more diversified future demands [1]. However, the cultivation of bioenergy crops on utilized arable lands increasingly creates a conflict with food production and poses important issues on the sustainability of this option [4-6].

In that context, the concept of marginal land has obtained more scientific and policy interest, being considered as a potential alternative for producing bioenergy and other non-food products from biomass $[4,6]$, while overcoming the environmental and social challenges associated with the new production.

The concept of marginal land has been very widely discussed by many researchers, although a common view has not been reached yet. The term "marginal land" may be ambiguous. Typically, poor quality land has been associated with marginal land, but even productive land in Southern Spain, for 
example, could be categorized as relatively marginal compared to the Paris basin [7]. One of the first definitions was proposed by Ricardo (1817) [8] and by Hollander (1895) [9], who defined marginal lands as the poorest lands that are used above the margin of rent-paying land. According to different authors [10-12], marginal lands are areas where the cost-effective production of food is not possible under given site conditions, cultivation techniques, agricultural policies, and the macro-economic and legal conditions. In such cases, revenue is just equal to the cost of production [13]. Currently, the low economic return from agricultural activity is very often associated with the low crop production and the biophysical constraints affecting the lands. Therefore, marginal farm land is generally characterized by low food and feed crop productivity, due to soil and environmental limitations $[6,14,15]$.

From a physical and productive perspective, marginality is based on the levels of soil suitability and restrictions, which soil scientists and agronomists rely on for land use planning. It refers to land of poor quality that is susceptible to erosion or other degradative factors [16].

Studies on marginal land have been reported in the literature, but these lands are difficult to identify, as land definition and identification should ensure that both the biophysical constraints and the absence of other uses are covered [4,17]. In Europe, the project Marginal Lands for Growing Industrial Crops (Magic) [18] and Sustainable Exploitation of Biomass for Bioenergy from Marginal Lands Project (Seemla) [4], have both assessed and quantified the area of marginal land in Europe with special attention to the biophysical constraints of the agricultural and forest land (i.e., grassland, arable land, permanent crop land), using Geographical Information Systems (GIS) tools and without considering the socio-economic consequences. Moreover, GIS tools have been used in Spain to detect land with only one biophysical constraint [19], but there is no record of the general determination of the arable marginal farm land for the whole country. This paper identifies marginal land in Spain from an economic perspective but also identifying and correlating seven biophysical constraints in those areas where the productions of the traditional crops are not profitable in a country scale, thus providing an extra step in the methodology to identify marginal lands.

In Spain, traditional agriculture, especially the farming of herbaceous crops under rainfed conditions, often provides low economic returns. This situation has worsened since 2010, when the prices for the main inputs used in growing traditional rainfed winter cereals has increased yearly, climbing to over $50 € \mathrm{ha}^{-1}$ between 2010 and 2016. Costs increments of fertilizers, seed, and herbicides have increased by $26 \%, 31 \%$, and $22 \%$, respectively, over this period. This data showed a reduction of around 35\% in the profit margins of rainfed crop production [20]. Consequently, from 1986 to 2016, the number of Spanish farms has declined by around 60\%, from 2,284,900 in 1989 to 945,024 in 2016. More than 2 million hectares have been abandoned for agricultural purposes during that period [21,22].

Spanish agriculture has around 17 million hectares (ha) of crop land, 10 million ha of which are rainfed herbaceous crops and fallow land [23]. Part of the crop land is at a higher risk of abandonment and it is imperative to understand the reasons for this marginality and find sustainable alternatives to correct the situation.

In the described context the general objective of this study was to the define areas where traditional food crops are not economically sustainable and could be substituted by energy crops without changing the land use.

The specific purposes of the study were the identification and map marginal rainfed arable lands in Spain, based on the profitability of the principal winter cereals cultivated, and determine the existing biophysical constraints. Additionally, other lands with similar biophysical constraints of marginality are also identified. 


\section{Materials and Methods}

\subsection{Study Area}

The study analyzed arable land under rainfed conditions that is dedicated to herbaceous crop production in Spain, excluding the North African Spanish autonomous cities of Ceuta and Melilla. The study area has an extension of about 10 million hectares over divided into 8122 municipalities.

To determine what can be considered marginal agricultural land in Spain, we studied the profit margin of Spain's principal crops (wheat and barley), considering the surface sown in the whole territory under rainfed conditions. Wheat and barley represent $80 \%$ of the total herbaceous crop surface sown under rainfed conditions [24]. The net margins of these crops can help determine the areas with economic constraints, where farmers cannot recover the cultivation costs. These areas have sustainability problems and are the ones farmers tend to abandon first [10].

Once the threshold to cover the cultivation cost has been determined, the spatial location of the areas is carried out using a database from the Spanish Ministry of Agriculture. This database is composed of the annual average production of winter cereals in Spain (wheat and barley among other crops), for each municipality over the last 39 years (1979-2018). This information is updated each year [25].

After observing the Spanish municipalities that could be considered as marginal land, where the production value hardly covered the cultivation costs of wheat and barley under rainfed conditions, the next step was to map and analyze the biophysical constraints in these selected areas. This also included identifying if these biophysical constraints affected other areas where the average production for each municipality was higher than the threshold and only a part of the municipality could be considered as marginal. This enabled a more precise determination of the areas with biophysical constraints within the Spanish rainfed agricultural system.

\subsection{Economic Study}

The methodology used to determine the profit margin of the two reference crops was based on the minimum production per hectare that farmers need to recover production costs. The crops inputs were calculated and included the machinery (investment, depreciation, maintenance costs, and fuel) (Table 1), labor costs, seeds, phytosanitary products, and fertilizers (Table 2). The output produced by a farm was the grain yield. The commodity costs, machinery costs, and output prices over the last six years were provided by the Spanish Ministry of Agriculture [26,27].

Table 1. Hourly costs and labor for each type of agricultural work.

\begin{tabular}{|c|c|c|c|c|c|}
\hline Labor & $\begin{array}{c}\text { Fuel } \\
\left(1 \mathrm{ha}^{-1}\right)\end{array}$ & $\begin{array}{c}\text { Hourly Rate } \\
\text { per Labor } \\
\left(\mathrm{h} \mathrm{ha}^{-1}\right)\end{array}$ & $\begin{array}{c}\text { Tractor }+ \\
\text { Implement } \\
\text { Costs }\left(€ \text { ha }^{-1}\right)\end{array}$ & $\begin{array}{l}\text { Labor Costs } \\
\quad\left(€ \mathrm{ha}^{-1}\right)\end{array}$ & $\begin{array}{c}\text { Total } \\
\left(€ \mathrm{ha}^{-1}\right)\end{array}$ \\
\hline Tillage & 13.9 & 0.98 & 33.59 & 9.80 & 43.39 \\
\hline Base Fertilization & 1.0 & 0.09 & 6.24 & 0.87 & 7.11 \\
\hline Cultivate & 6.1 & 0.56 & 12.62 & 5.55 & 18.17 \\
\hline Seeding & 4.3 & 0.39 & 15.48 & 3.92 & 19.40 \\
\hline Top dressing & 0.7 & 0.07 & 5.24 & 0.87 & 6.11 \\
\hline Rolling & 2.7 & 0.21 & 3.61 & 2.10 & 5.71 \\
\hline Herbicide treatment & 0.7 & 0.07 & 4.60 & 0.65 & 5.25 \\
\hline Harvest & 17.1 & 0.44 & 39.60 & 4.40 & 44.00 \\
\hline
\end{tabular}

Machinery costs were based on traditional tillage management, which is common in Spain, using a $112 \mathrm{KW}$ tractor and suitable agricultural equipment. With respect to the agricultural works, we considered the hourly rate for each agricultural activity (i.e., tillage, cultivation, base fertilization, sowing, herbicide treatment, top dressing, rolling and harvesting), a fuel price of $0.89 € 1^{-1}$ [27], as 
well as a labor cost of $10 € \mathrm{~h}^{-1}$ [27]. Table 1 shows the costs of each agricultural activity taking the labor into account.

Table 2. Inputs and outputs studied for wheat and barley grain yield.

\begin{tabular}{|c|c|c|c|}
\hline & Units & Wheat & Barley \\
\hline Machinery costs + labor & $€ \mathrm{ha}^{-1}$ & 149 & 149 \\
\hline \multicolumn{4}{|l|}{ Base fertilizers for grain yield: } \\
\hline $1.0 \mathrm{Mg} \mathrm{ha}^{-1}$ & \multirow{5}{*}{$€ \mathrm{ha}^{-1}$} & 50 & 40 \\
\hline $1.5 \mathrm{Mg} \mathrm{ha}^{-1}$ & & 63 & 48 \\
\hline $2.0 \mathrm{Mg} \mathrm{ha}^{-1}$ & & 84 & 60 \\
\hline $2.5 \mathrm{Mg} \mathrm{ha}^{-1}$ & & 100 & 80 \\
\hline $3.0 \mathrm{Mg} \mathrm{ha}^{-1}$ & & 125 & 80 \\
\hline Seeds & $€ \mathrm{ha}^{-1}$ & 39 & 33 \\
\hline Herbicides & $€$ ha $^{-1}$ & 23 & 22 \\
\hline \multicolumn{4}{|l|}{ Top dressing for grain yield: } \\
\hline $1.0 \mathrm{Mg} \mathrm{ha}^{-1}$ & \multirow{5}{*}{$€ \mathrm{ha}^{-1}$} & 20 & 20 \\
\hline $1.5 \mathrm{Mg} \mathrm{ha}^{-1}$ & & 25 & 25 \\
\hline $2.0 \mathrm{Mg} \mathrm{ha}^{-1}$ & & 30 & 30 \\
\hline $2.5 \mathrm{Mg} \mathrm{ha}^{-1}$ & & 41 & 41 \\
\hline $3.0 \mathrm{Mg} \mathrm{ha}^{-1}$ & & 50 & 50 \\
\hline Output & $€ \mathrm{Mg}^{-1}$ & 190 & 161 \\
\hline
\end{tabular}

Basal fertilization was calculated using the commercial fertilizer complex NPK 8-24-8 for wheat and 8-15-15 for barley, as well as top dressing with high $\mathrm{N}$ complex calcium ammonium nitrate (27\%). Also included was the expected harvest to calculate the restitutions [28]. Seeding was established at $0.19 \mathrm{Mg} \mathrm{ha}^{-1}$ for wheat and $0.18 \mathrm{Mg} \mathrm{ha}^{-1}$ for barley [29]. The herbicide treatment was calculated for killing broadleaf and gramineous weeds.

Common agricultural policy (CAP) direct aids, land rent, and opportunity costs were not considered for different reasons. The CAP direct payments and land rent as income and cost are very important, but they have high variability within Spanish agricultural farms and it is not possible to compare the averages due to the lack of reliable data. Opportunity cost is a comparative term, and it is not a real cost incurred by cultivation.

\subsection{Biophysical Constraints}

Seven biophysical constraint factors were considered in the areas where the production value did not cover the production costs: Type, depth, stoniness, organic matter content $(\mathrm{OM}), \mathrm{pH}$ and salinity of the soil, and the annual precipitation.

Soil classification was based on the four main types of soil found in Spain according to the USDA soil Taxonomy: Inceptisol, Alfisol, Entisol, and Aridisol. Inceptisol and Alfisol are soils that do not require irrigation to achieve competitive yields. They have suitable water and nutrient retention, as opposed to the other two categories Entisol and Aridisol, which are not suitable for rainfed agriculture. Aridisol is representative of arid regions where the evapotranspiration of crops under standard conditions (ETc) is greater than the perspiration throughout most of the year. Hence, the humidity regime is usually arid. Entisol is a soil with very low profile development and almost no differences between horizons [30].

Soil depth was observed from the top soil to the rock bed. The vertical distribution of the rock systems has a very significant impact on yield [31]. This implies that grater uniformity in the distribution of deep roots could improve the economic returns of the crops. Winter cereals make up $90 \%-100 \%$ of the root system in the first $100 \mathrm{~cm}$ of the soil. 
Stoniness is an important factor for crops, because of its association with farm equipment problems, its relation to root expansion in the soil, and water retention. Soil is characterized as "stony" when the stone concentration volume is higher than $15 \%$ of the soil fraction [32].

Organic matter content is related to soil fertility. The desirable level of organic matter in agricultural soils is at least around $2 \%$, although it is possible to grow winter cereals with OM content higher than $1 \%$ [33]. Consequently, lands with less than $1 \%$ OM content were selected as marginal lands.

Soil $\mathrm{pH}$ is a relevant parameter in plant productivity, because the availability of essential nutrient for plants depends on this value. If the $\mathrm{pH}$ of the soil is not suitable, the harvest can be reduced to the point of affecting crop growth. Most plants need a soil $\mathrm{pH}$ between 5.5 and 7.5 for optimum nutrient absorption. For example, the ideal $\mathrm{pH}$ for winter cereals is 6.5 [34], although the cereals can be grown with a $\mathrm{pH}$ of 8 [35]. A pH lower than 6 could affect magnesium or nitrogen, and a $\mathrm{pH}$ higher than 7 could affect manganese availability [36].

Salinity was also observed. When the winter cereals were sown on flat surfaces, the limit of salinity resistance for wheat and barley was $4 \mathrm{dS} \mathrm{m}^{-1}$. Values of soil salinity above $4 \mathrm{dS} \mathrm{m}^{-1}$ tend to affect plant productivity, although they can resist a salinity content of $6 \mathrm{dS} \mathrm{m} \mathrm{m}^{-1}$ [37].

With regard to climate, winter cereals need at least $400 \mathrm{~mm}$ of precipitation in Spain to complete the growth cycle [38]. Thus, the fact that the annual rainfall is less than $400 \mathrm{~mm}$ poses a problem.

\subsection{Map Sources and Data Management}

The study used the Environmental Research Institute (ESRI. Inc.) and ArcMAPTM Spatial Analyst. ArcGIS version 10.5 was the GIS software used for organizing, aggregating, and depicting the cartographic data.

Soil characteristic maps were provided as a system for automated soil mapping based on a global compilation of soil profile data and publicly available remote sensing data called SoilGrids. The datasets for establishing the precipitation constraints were the average accumulated annual rainfall for 30 years, from 1975 to 2005 [39].

\subsection{Bioenergy Potential}

The bioenergy potential was estimated using the BIORAISE CE application [40]. BIORAISE $\mathrm{CE}$ is a tool that provides information at the municipal level in Spain regarding different crops for biomass production. The method is based on the use of a national mapping of land uses (Land Occupation Information System in Spain, SIOSE) [41] and crop production model for the different species considered. Within this base layer (SIOSE), rainfed and irrigated areas can be differentiated and on it, defined according to criteria defined for each crop, the so-called Homogeneous Agronomic Areas (AAH), which are geographical areas with the same productivity each crop. Once the AAH are ready, the surface distribution maps of potential energy crops are obtained. The yield was calculated for each energy crop in each AAH, based on the experimental information available for the energy crops.

Cardoon (Cynara cardunculus L.) and triticale ( $x$ Triticosecale) were chosen to its adaptability to rainfed condition. Cardoon is a perennial crop that is harvested annually with a low calorific value (LCV) of $16.7 \mathrm{GJ} \mathrm{t}^{-1}$ dry matter (dm), and triticale is an annual crop with a LCV $16.8 \mathrm{GJ} \mathrm{t}^{-1} \mathrm{dm}_{\text {[40]. }}$

Triticale yields were estimated as the whole biomass production harvested at the grain medium milk stage (Z75 stage in Zadoks scale) [42] and cardoon yields were estimated at the end of the crop cycle [43].

\section{Results}

\subsection{Economic Threshold}

The principal input and output values calculated according to Section 2.2 are shown in Table 2. 
Based on the production costs and the output prices over the period studied (Table 2), we found that annual productivity of $\leq 1.5 \mathrm{Mg} \mathrm{ha}^{-1}$ of wheat and barley was insufficient to cover the cultivation costs (Table 3).

Table 3. Costs of crop inputs and outputs, and gross margin calculated according to the grain yield.

\begin{tabular}{ccccccc}
\hline \multirow{2}{*}{$\begin{array}{c}\text { Grain Yield } \\
\left(\mathbf{M g ~ h a}^{-\mathbf{1}}\right)\end{array}$} & \multicolumn{2}{c}{ Input $\left(\boldsymbol{(} \mathbf{h a}^{\mathbf{- 1}}\right)$} & \multicolumn{2}{c}{ Output $\left(\boldsymbol{(} \mathbf{h a}^{-\mathbf{1}}\right)$} & \multicolumn{2}{c}{ Gross Margin $\left(\boldsymbol{€} \mathbf{h a}^{-\mathbf{1}}\right)$} \\
\cline { 2 - 7 } & Wheat & Barley & Wheat & Barley & Wheat & Barley \\
\hline 1.0 & 280 & 263 & 190 & 161 & -90 & -102 \\
$\mathbf{1 . 5}$ & $\mathbf{2 9 8}$ & $\mathbf{2 7 6}$ & $\mathbf{2 8 5}$ & $\mathbf{2 4 1}$ & $-\mathbf{1 3}$ & $-\mathbf{3 5}$ \\
2.0 & 324 & 293 & 380 & 322 & 56 & 29 \\
2.5 & 351 & 324 & 475 & 403 & 124 & 79 \\
3.0 & 385 & 333 & 570 & 483 & 185 & 150 \\
\hline
\end{tabular}

For both crops, about $50 \%$ of production costs were related to machinery, fuel and labor, whilst the other $50 \%$ was related to commodities in the following proportions: $30 \%$ fertilizers, $10 \%$ seeds, and $10 \%$ herbicides.

\subsection{Identification of Marginal Areas and Biophysical Constraints}

The combined area of wheat and barley with an average yield of $1.5 \mathrm{Mg} \mathrm{ha}^{-1}$ or less was predominant in rainfed conditions agricultural area of 1678 Spanish municipalities and covered $1,960,316$ ha of arable land, which is almost $20 \%$ of the national total rainfed area $11.5 \%$ of the total cropland area, and $4 \%$ of the total surface of Spain.

The total surface area affected by at least one of the biophysical constraints was 1,920,940 ha. Table 4 shows the number of hectares affected by each biophysical constraint.

Table 4. Biophysical constraint surface for Spanish areas under rainfed conditions in municipalities with an average productivity $\leq 1.5 \mathrm{Mg} \mathrm{ha}^{-1}$.

\begin{tabular}{cc}
\hline Biophysical Constraints & Surface Affected (ha) \\
\hline Stoniness & $1,383,612$ \\
Organic matter $(\mathrm{OM})$ & $1,171,564$ \\
Soil depth & 505,866 \\
Soil type & 449,346 \\
Annual rainfall & 435,093 \\
Salinity & 281,879 \\
pH & 162,261 \\
\hline
\end{tabular}

Moreover, in Spain, 7,971,373 ha have been identified as having at least one biophysical constraint that was similar to the constraints studied for areas with yields $\leq 1.5 \mathrm{Mg} \mathrm{ha}^{-1}$ under rainfed conditions (Table 5). However, in these areas, the average productivity of wheat and barley for the municipalities was higher than $1.5 \mathrm{Mg} \mathrm{ha}^{-1}$, which was probably preventing/delaying the abandonment of that surface.

Comparing the different biophysical constraints (Table 6), a high relationship among the different constraints can be observed. Soils with constraints such as, stoniness, low depth, type of soil, low annual rainfall and saline soils present OM constraints in over $57 \%$ of their surface. 
Table 5. Biophysical constraints surface for Spain in arable rainfed lands, with average municipal yields $>1.5 \mathrm{Mg} \mathrm{ha}^{-1}$.

\begin{tabular}{cc}
\hline Biophysical Constraints & Surface Affected (ha) \\
\hline Stoniness & $3,183,996$ \\
Organic matter $(\mathrm{OM})$ & $6,011,766$ \\
Soil depth & 894,298 \\
Soil type & $1,797,789$ \\
Annual rainfall & 673,591 \\
Salinity & $1,419,527$ \\
pH & 624,906 \\
\hline
\end{tabular}

Table 6. Relationship of the overlapping of two biophysical constraints (Values expressed in \% on surface).

\begin{tabular}{cccccccc}
\hline $\begin{array}{c}\text { Biophysical } \\
\text { Constraints }\end{array}$ & $\begin{array}{c}\text { Stoniness } \\
\mathbf{( \% )}\end{array}$ & OM (\%) & $\begin{array}{c}\text { Soil } \\
\text { Depth (\%) }\end{array}$ & $\begin{array}{c}\text { Soil Type } \\
\mathbf{( \% )}\end{array}$ & $\begin{array}{c}\text { A. Rainfall } \\
\mathbf{( \% )}\end{array}$ & $\begin{array}{c}\text { Salinity } \\
\mathbf{( \% )}\end{array}$ & pH (\%) \\
\hline Stoniness & - & 58 & 24 & 17 & 6 & 10 & 4 \\
OM & 37 & - & 16 & 18 & 14 & 18 & 4 \\
Soil depth & 78 & 82 & - & 2 & 2 & 5 & 0 \\
Soil type & 35 & 57 & 1 & - & 29 & 26 & 30 \\
A. rainfall & 24 & 89 & 3 & 58 & - & 40 & 21 \\
Salinity & 27 & 78 & 4 & 34 & 26 & - & 8 \\
pH & 26 & 36 & 1 & 84 & 29 & 16 & - \\
\hline
\end{tabular}

\subsection{Spatial Location}

Arable lands under rainfed conditions with wheat and barley productivity $\leq 1.5 \mathrm{Mg} \mathrm{ha}^{-1}$ are shown in Figure 1. The Southern and Western parts, in addition to the Canary and Balearic Islands are the principal areas of Spain where low production rates are most common.

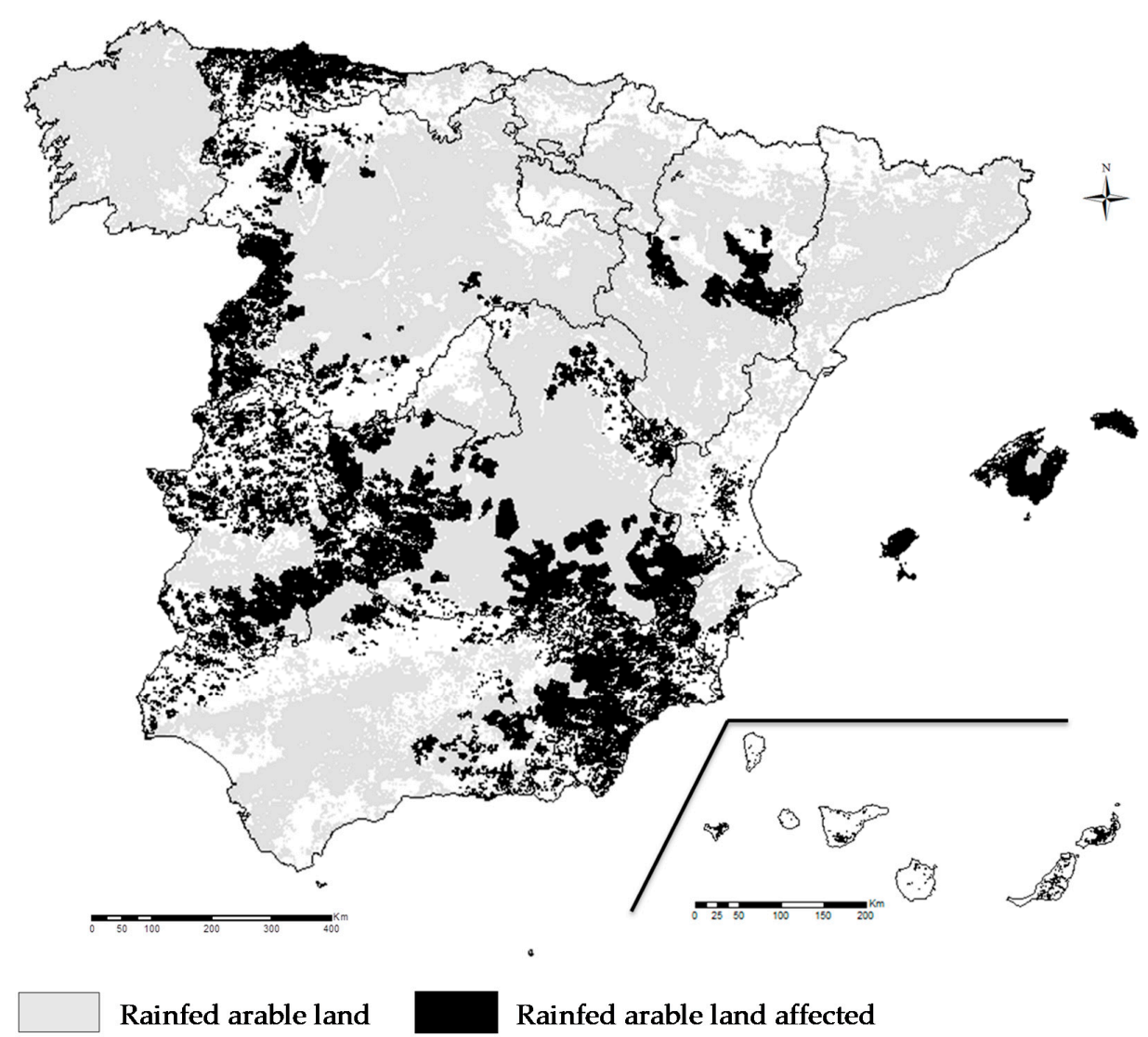

Figure 1. Spatial distribution of rainfed arable land with principal winter cereal yield $\leq 1.5 \mathrm{Mg} \mathrm{ha}^{-1}$. 
Moreover, Figures 2-8 show the spatial distribution of the different biophysical constraints that were studied across all the rainfed arable land in Spain, which also affected the areas with low yield. Specifically, areas whose depth is lower than $100 \mathrm{~cm}$ (Figure 2); areas where the OM content is lower than 1\%; (Figure 3); areas with pH below 6 and higher than 8 (Figure 4); areas whose volume of stones is higher than 15\% (Figure 5); areas where the type of soil is Entisol or Aridisol, according to TAXOUSDA classification (Figure 6); areas with the salt content higher than $4 \mathrm{dS} \mathrm{m}^{-1}$ (Figure 7) and finally, areas whose historic annual rainfall is lower than $400 \mathrm{~mm}$ (Figure 8).

Overlapping all the figures, Figure 9 shows the total area with the constraints in the study.

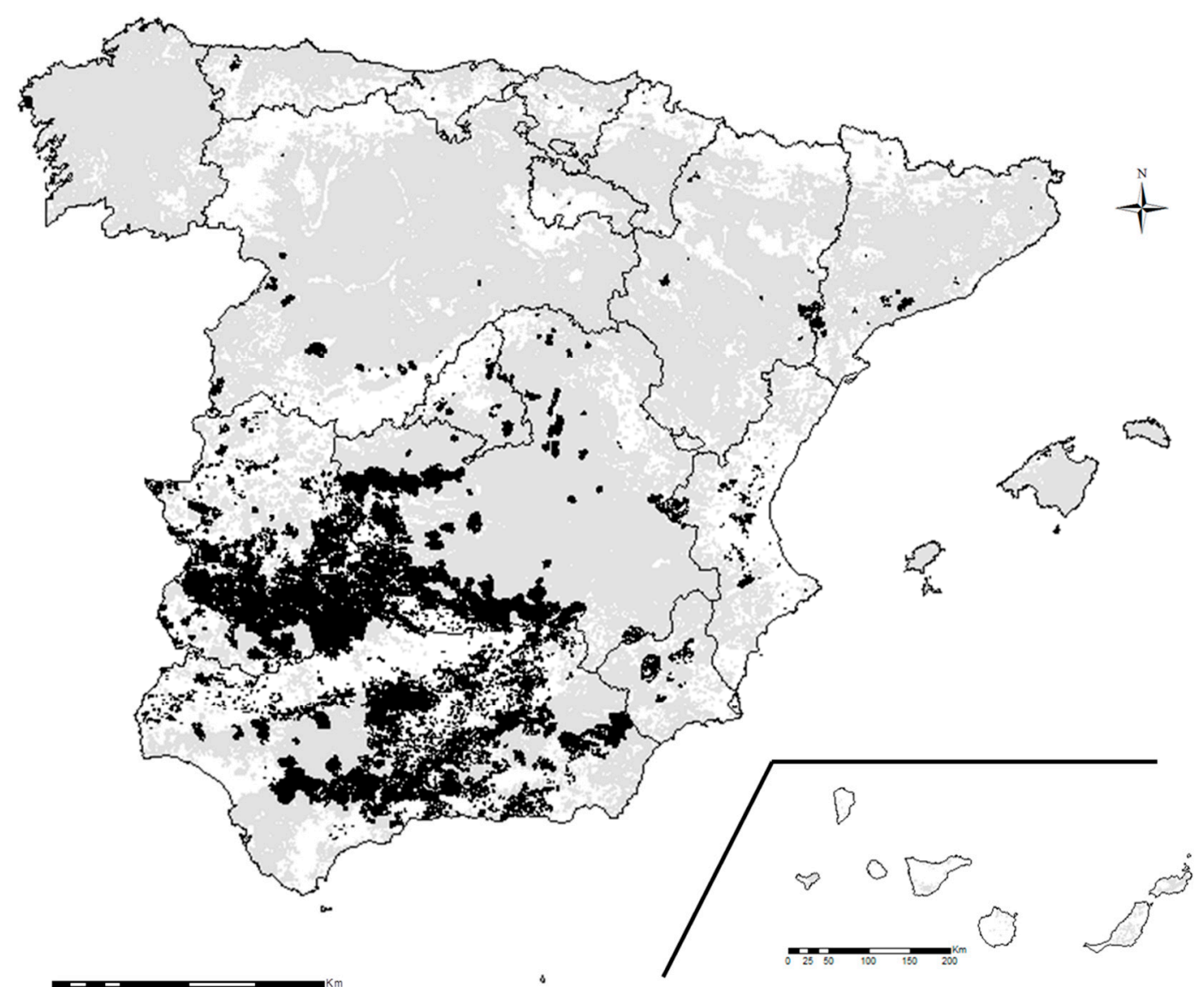

Rainfed arable land

Arable land affected by the biophysical constraint

Figure 2. Rainfed arable land with soil a depth of $<100 \mathrm{~cm}$.

\subsection{Bioenergy Potential}

Triticale and cardoon were selected among the crops contained in BIORAISE CE to determine the biomass potential in the identified marginal area due to its adaptability to those areas. According to calculations of BIORAISE-CE, potential productivity of triticale biomass was $4.96 \pm 1.24 \mathrm{Mg} \mathrm{dm} \mathrm{ha}^{-1}$ over $1,838,978$ ha ( $96 \%$ of the marginal study area), whilst $1,571,827$ ha ( $82 \%$ of the area) was suitable for cardoon with an average yield of $10.47 \pm 2.77 \mathrm{Mg} \mathrm{dm} \mathrm{ha}{ }^{-1} \cdot \mathrm{yr}^{-1}$. Therefore, biomass production potentials were determined, $83.33 \mathrm{GJ} \mathrm{ha}^{-1}$ for triticale and $174.85 \mathrm{GJ} \mathrm{ha}^{-1}$ for cardoon. 


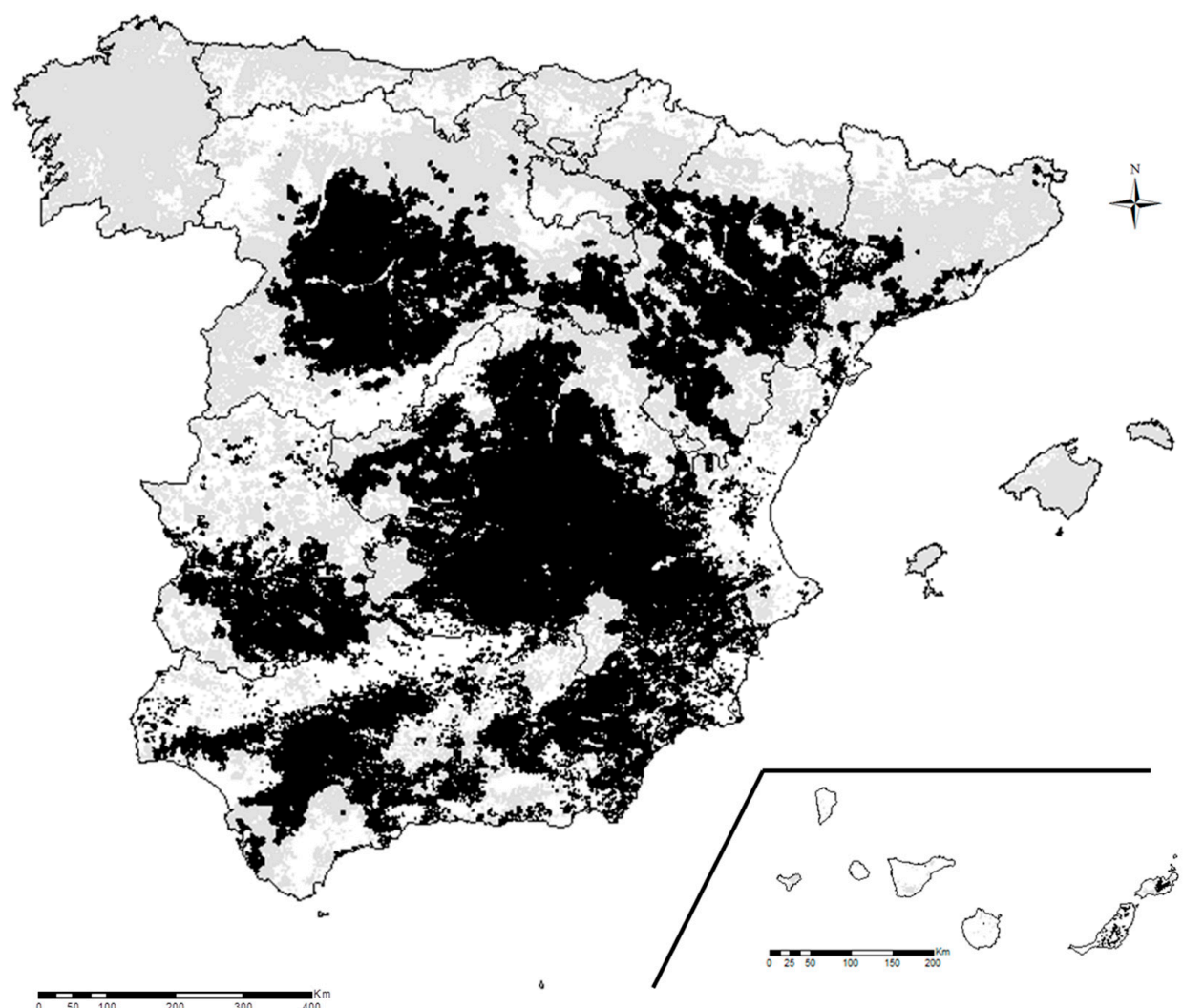

Rainfed arable land

Arable land affected by the biophysical constraint

Figure 3. Rainfed arable land with OM content $<1 \%$.

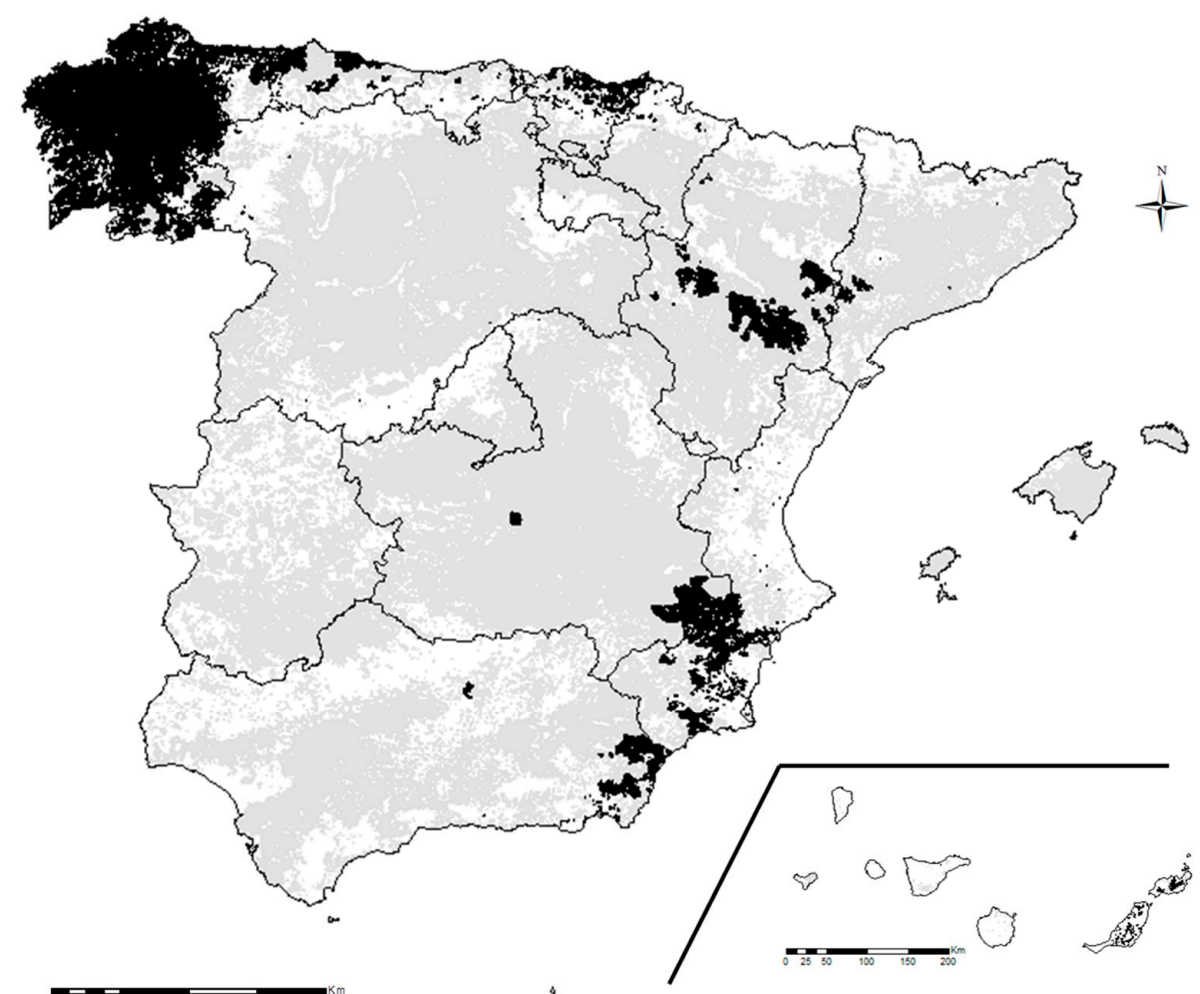

Rainfed arable land

Arable land affected by the biophysical constraint

Figure 4. Rainfed arable land with $\mathrm{pH}<6$ and $>8$. 


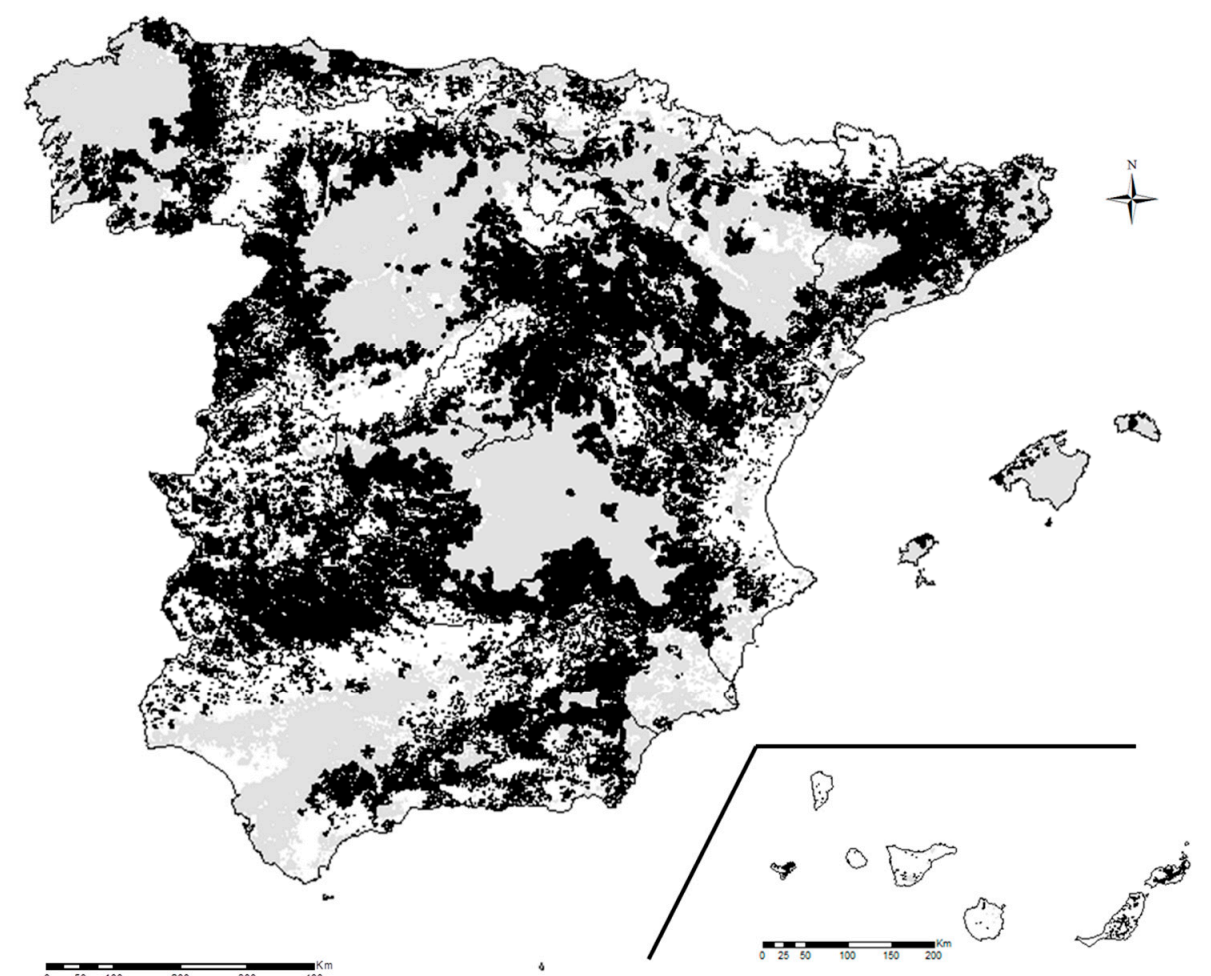

Rainfed arable land Arable land affected by the biophysical constraint

Figure 5. Rainfed arable land with a volume of stones $\geq 15 \%$.

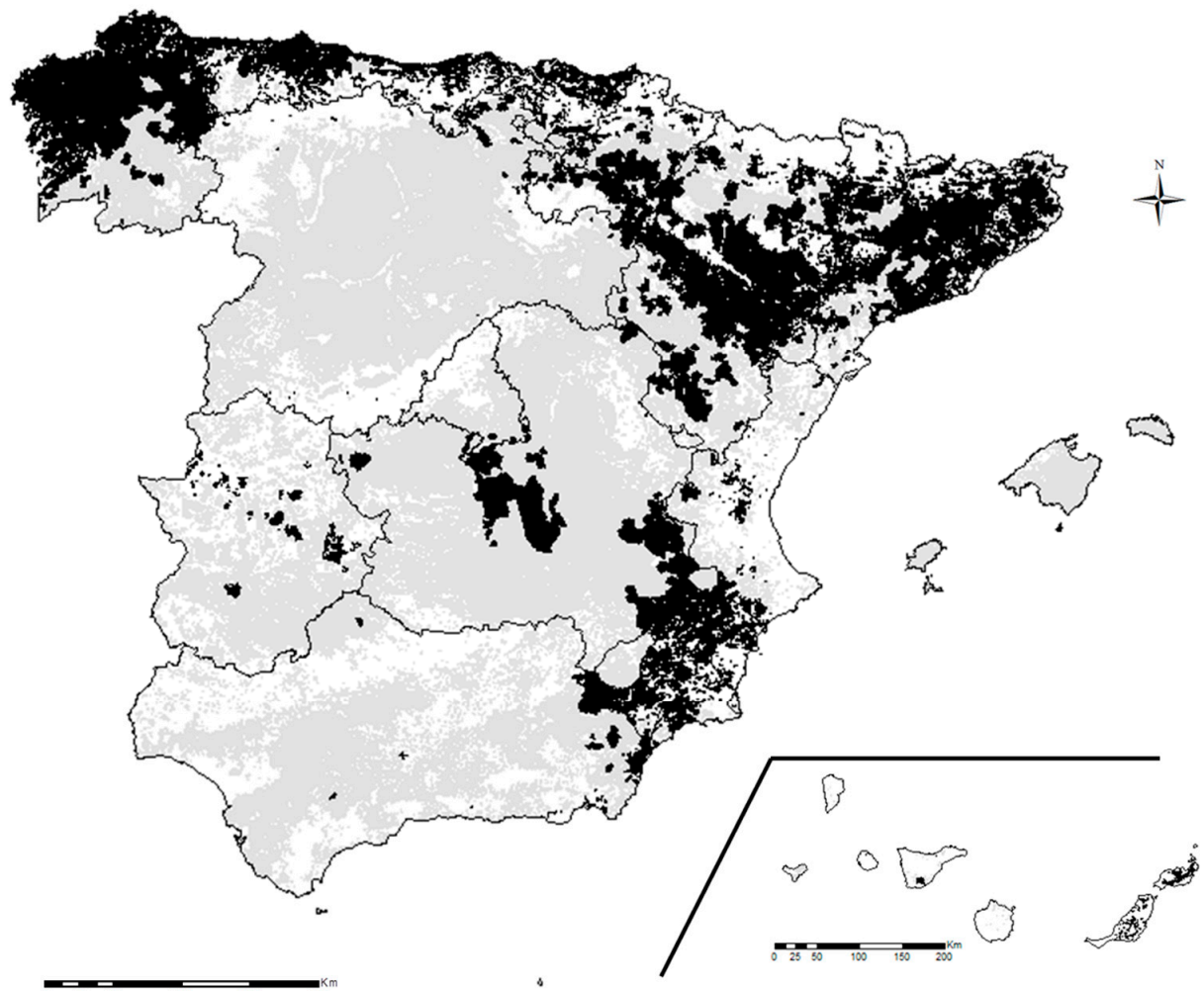

Rainfed arable land $\quad$ Arable land affected by the biophysical constraint

Figure 6. Rainfed arable land with soil types Entisol and Aridisol, according to the TAXOUSDA classification. 


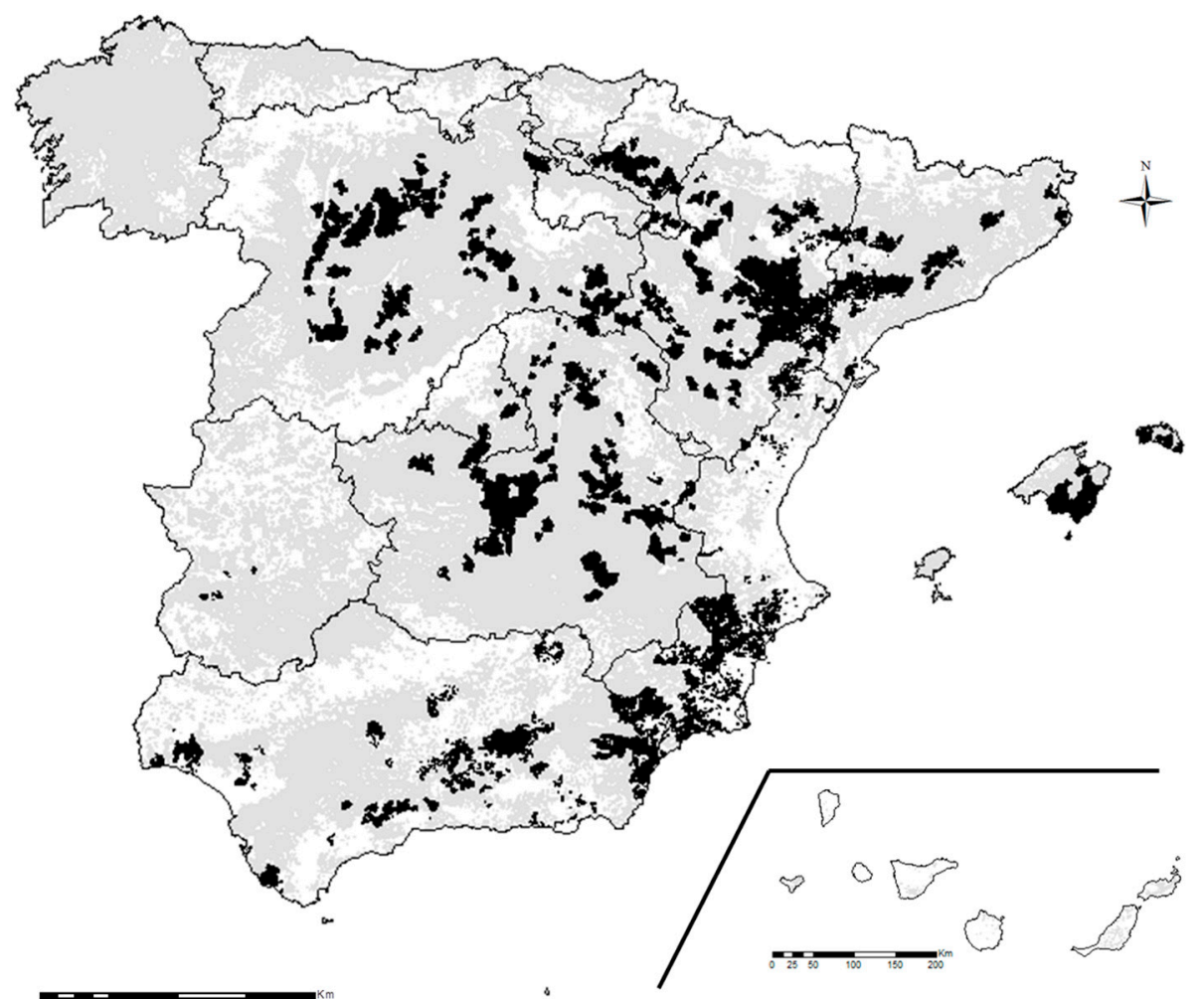

Rainfed arable land

Arable land affected by the biophysical constraint

Figure 7. Rainfed arable land with salt levels $>4 \mathrm{dS} \mathrm{m}^{-1}$.

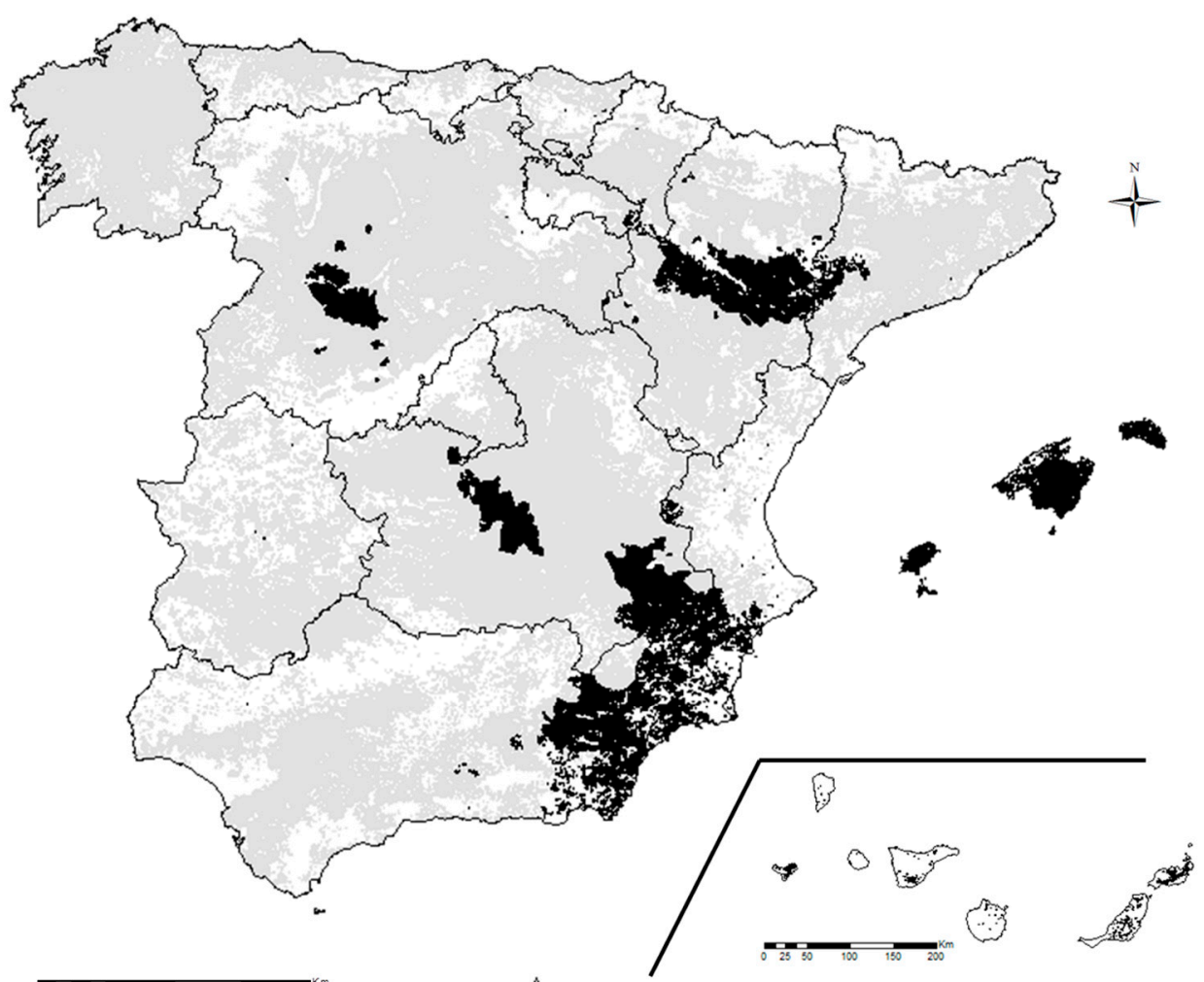

Rainfed arable land

Arable land affected by the biophysical constraint

Figure 8. Rainfed arable land with annual precipitation less than $400 \mathrm{~mm}$. 


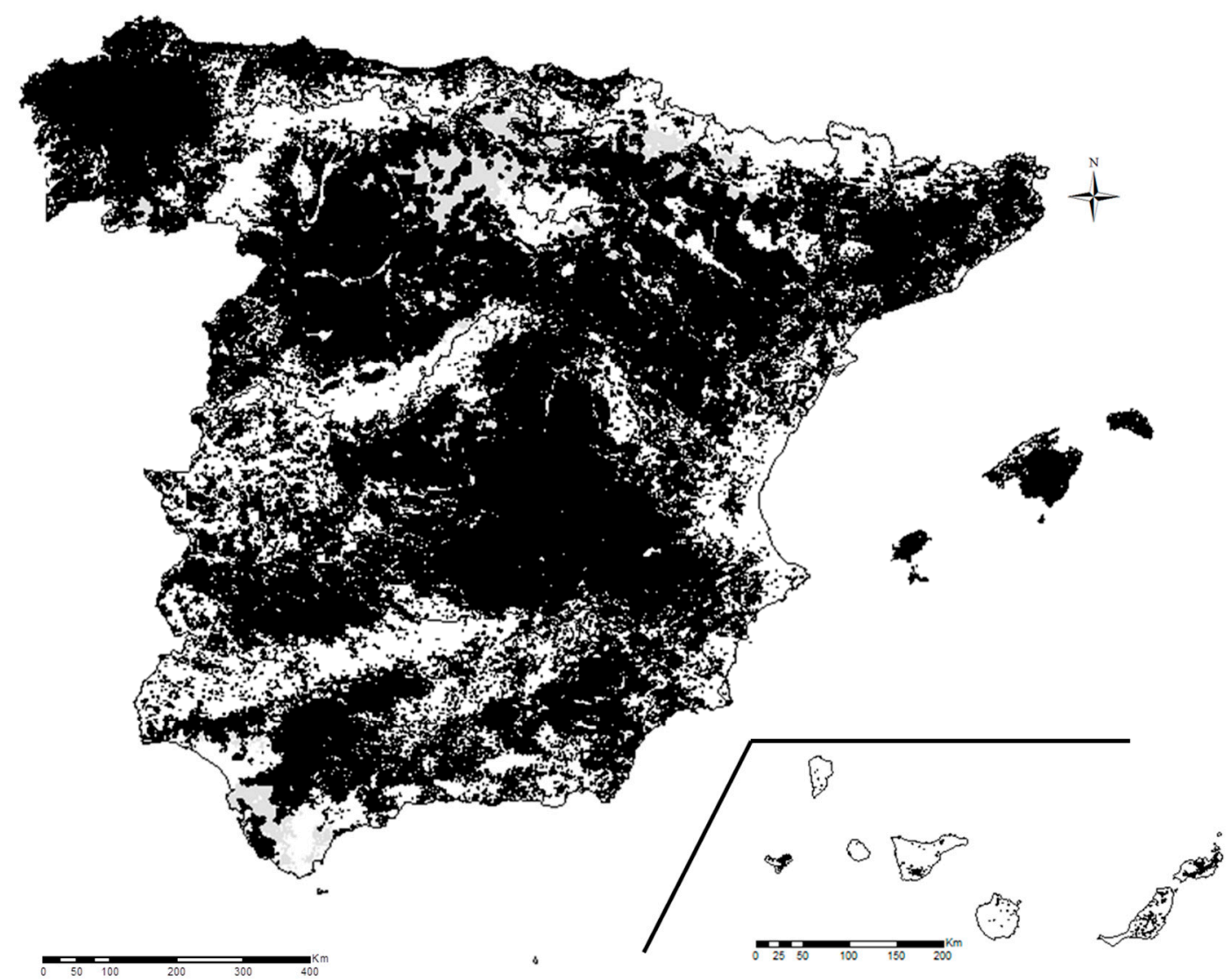

Rainfed arable land without economic and biophysical constraints.

Rainfed arable land with economic and/or biophysical constraints.

Figure 9. Spatial distribution of the rainfed arable land with total constraints considered.

\section{Discussion}

Marginal land studies defined marginal agricultural lands as land that not worth cultivating with agro-food crops because the number of economic and biophysical constraints such as extreme climate conditions, soil and terrain handicaps, long distance to the markets among others [44]. According to our study findings, in Spain, there are 9,931,689 ha of arable land under rainfed conditions that have some biophysical and/or economic constraints. The above area is divided into 1,960,316 ha of the present arable marginal land and 7,971,373 ha with at least one biophysical constraint, which could be potential marginal land in the future, depending on whether the land continues to be managed in the same way. Low OM content is the biophysical constraint with the highest overlapping, with the rest of the biophysical constraints ranging between $36 \%$ and $89 \%$. Stoniness is another biophysical constraint with a high level of overlap, principally with soil depth parameter which has an overlapping of $78 \%$.

The profit margin of the crops increases when yields increase. The economic results obtained in this study were similar to other studies carried out in the Ebro valley (Spain) for wheat and barley under rainfed conditions, which reported inputs of $320 € \mathrm{ha}^{-1}$ for yields between 2 and $2.5 \mathrm{Mg} \mathrm{ha}^{-1}$ for barley and $389 € \mathrm{ha}^{-1}$ for winter wheat with grain productivity over $3.0 \mathrm{Mg} \mathrm{ha}^{-1}$ [45].

Out of the 1,960,316 ha characterized as marginal agricultural land in the municipalities, there were only 39,376 ha $(2 \%)$ which were outside of the thresholds of the biophysical criteria proposed. The area assessed as having economic restrictions represented around $20 \%$ of the Spanish rainfed arable area, $11.5 \%$ of the total cropland area, and $4 \%$ of the total surface. In Europe, approximately 257 Mha has been identified as marginal including grassland, and the available area for biomass production has been approximately 58.2 Mha [4], in this respect Spain represents $3.4 \%$ of the total surface available in Europe under marginal conditions for growing energy crops. 
In relation to the biomass production in arable marginal land, the results obtained using the BIORAISE CE for cardoon were within the range of 3.4-25.2 $\mathrm{Mg} \mathrm{dm} \mathrm{ha}^{-1}$, which were similar to the results obtained in another ten-year study in Spain [46]. This high variability in yield is due to the fact that cardoon depends heavily on precipitation and deep soil. With $529 \mathrm{~mm}$ of annual precipitation yield was $23.1 \mathrm{Mg} \mathrm{dm} \mathrm{ha}{ }^{-1}$ and $6.5 \mathrm{Mg} \mathrm{dm} \mathrm{ha}^{-1}$ with $280 \mathrm{~mm}$ of annual precipitation [43]. Large scale cultivation of the cardoon in southern Europe, Portugal, with 77.4 ha, biomass average yield was estimated at $7.5 \mathrm{Mg} \mathrm{dm} \mathrm{ha}{ }^{-1}$ with $556 \mathrm{~mm}$ annual precipitation [47]. Furthermore, cardoon was included in the European project Optimization of Perennial Grasses for Biomass Production in the Mediterranean Area (OPTIMA) due to its higher yield and adaptability to the Mediterranean marginal areas [48], with the aim to establish new strategies for the sustainable use of the marginal land in Mediterranean areas. These facts exhibit its suitability for the inclusion in energy-cropping systems on marginal lands [49]. Triticale yields were similar to other results obtained in seven locations in Spain with four different cultivars, which were between 2.7 and $8 \mathrm{Mg} \mathrm{dm} \mathrm{ha}^{-1}$ [50]. Moreover, in the Singular and Strategic Project "On Cultivos", a series of trials were carried out with triticale over a period of 3 years in different provinces in eight autonomous communities in Spain, producing yields of whole biomass between 1.6 to $12.4 \mathrm{Mg} \mathrm{dm} \mathrm{ha}^{-1}$ [51]. Field trials carried out in two locations for two years in Northern Spain, with three different varieties, showed yields between 4.60 and $7.84 \mathrm{Mg} \mathrm{dm}$ $\mathrm{ha}^{-1}$ for the province of Soria, and between 6.20 and $10.25 \mathrm{Mg} \mathrm{dm} \mathrm{ha}^{-1}$ in the province of León [52]. In many cases these crops are adapted to poor soils, having adequate production in arable marginal land [6].

Perennial lignocellulosic crops are less flexible than the annual crops in terms of propagation, processing, and utilization, but they can provide profitable alternatives to food crops [53]. Moreover, soil erosion and polluted lands can be reduced by the substitutions of conventional crops grown on marginal lands for bioenergy purpose with low-input perennial grasses [54].

The total primary energy consumption in Spain was 123,868 ktep in 2015 [55]; hence, according to the results of this study, the production of biomass in this area would cover $3 \%-5 \%$ of Spain's needs for primary energy. Energy production would increase if the biomass is mixed with digestate or other animal manures or permanent grassland, meadows and residual grass for biogas purpose [2,56-59].

Marginal lands and lands with biophysical constraints have the potential to grow energy crops, but it would be necessary to conduct an in-depth study to analyze yields and economic viability. In the last several years, perennial grasses such as tall wheatgrass (Thinopyrum ponticum Podp.) [60] have shown a higher potential for soil carbon sequestration compared to annual crops, as a result of the continuous ground coverage, reduced soil disturbance, and enhanced root biomass production [61]. Furthermore, perennial grasses have reported higher yields in areas with biophysical constraints than winter wheat [62]. Owing to the climate and soil conditions, the range of species that may be suitable for such conditions is not broad; hence, more research regarding these issues is necessary. Moreover, perennial grasses are habitats for many species of flora and fauna as permanent grassland and meadows [56]. The successful implementation of energy crops as an integral part of traditional production systems is a difficult task that requires an accurate agronomic evaluation in terms of environmental adaptability, productivity, logistics, restricting factors, and synergies with crop rotation schemes; where crop production and input requirements are the most important issues in determining the suitability of different crops [53].

In this respect, establishing energy crops in marginal lands could be used as an instrument to avoid the abandonment of rural areas and to reach multiple EU policy targets, such as enhancing rural development, boosting the bio-economy, and reaching the greenhouse gases (GHG) mitigation targets.

\section{Conclusions}

The economic balance of wheat and barley under rainfed conditions indicates that yields $\leq 1.5 \mathrm{Mg} \mathrm{ha}^{-1}$ makes cultivating the land unprofitable for farmers using traditional management, which means these areas are considered marginal lands. The study of these areas shows clearly that 
these economic constraints are linked to biophysical constraints. The overlapping of biophysical constraints could make certain areas too sensitive for sustainable use by farmers. Low OM content is the most frequent biophysical constraint of those considered in the study.

The evolution of the mentioned land will depend on whether it continues to be managed in the same way. Changes in the preparation of the seed bed and changes in the crops sown in those areas could improve them. In this context, it is important that the selection of the adequate specie for each area by farmers does not associate the crop yields with the crop suitability for other purposes.

The bioenergy crop yield is also lower in marginal lands, therefore it should be necessary to assess the positive impacts that this activity has in the environment and in the rural areas. Avoiding the abandonment of these marginal areas by planting energy crops helps to achieve some of the objectives of the CAP for the period 2021-2027, using low-input agriculture, trough energy crops that can enhance the environment (enhance carbon soil restoration and avoid soil erosion) and also increase opportunities in rural areas. Moreover, the generation of energy using crops from those lands would not be in conflict with food production.

Additionally, the use of marginal lands may contribute to the EU policy objective to reduce $\mathrm{CO}_{2}$ emissions by $40 \%$ in 2030 and, in particular, to achieve the contribution of $32 \%$ with renewable sources to the total energy consumption in that year contained in the new Directive of Renewable Energies 2021-2030 that promotes the use of renewable energy sources.

The methodology developed in this work can be a step forward in the identification of marginal lands, and the identification of the constraint factors that make these areas marginal. It could be replicated in other EU countries with the same problems, principally in the Mediterranean basin.

Author Contributions: Conceptualization, C.S.C., P.C., and M.S.; methodology, C.S.C. and P.C.; validation, C.S.C., M.S., and P.C.; formal analysis, C.S.C., M.S., and P.C.; investigation, C.S.C.; resources, C.S.C. and P.C.; data curation, C.S.C.; writing-original draft preparation, C.S.C.; writing-review and editing, C.S.C., P.C., M.S., and J.C.; visualization, C.S.C.; supervision, P.C., M.S., and J.C.; funding acquisition, J.C.

Funding: This research was funded by European Commission, in the frame work of HORIZON 2020 RUR 07-2016 with the title "Marginal lands for Growing Industrial Crops: Turning a burden into an opportunity" (MAGIC) "grant number 727698".

Acknowledgments: The authors would like to thank to Eva Sevillano for her unbiased contribution to this work.

Conflicts of Interest: The authors declare no conflict of interest.

\section{References}

1. FAO. Global Agriculture towards 2050. How to Feed the World 2050. Available online: www.fao.org/.../ wsfs /.../How_to_Feed_the_World_in_2050.pdf (accessed on 1 April 2017).

2. Mantineo, M.; D'Agosta, G.M.; Copani, V.; Patane, C.; Cosentino, S.L. Biomass yield and energy balance of three perennial crops for energy use in the semi-arid Mediterranean environment. Field Crop Res. 2009, 114, 204-213. [CrossRef]

3. Sevigne, E.; Gasol, C.M.; Brun, F.; Rovira, L.; Pages, J.M.; Camps, F.; Rieradevall, J.; Gabarrell, X. Water and energy consumption of Populus spp. bioenergy systems: A case study in Southern Europe. Renew. Sustain. Energy Rev. 2011, 15, 1133-1140. [CrossRef]

4. Gerwin, W.; Repmann, F.; Spyridon, G.; Despoina, V.; Gounairs, N.; Baumgarten, W.; Christiane, V.; Keramitzis, D.; Kiourtsis, F.; Freese, D. Assessment and quantification of marginal lands for biomass production in Europe using soil quality indicators. Soil 2018, 4, 267-290. [CrossRef]

5. Dauber, J.; Miyake, S. To integrate or to segregate food crop and energy crop cultivation at the landscape scale? Perspectives on biodiversity conservation in agriculture in Europe. Energy Sustain. Soc. 2016, 11, 19. [CrossRef]

6. Mehmood, M.A.; Ibrahim, M.; Rashid, U.; Nawaz, M.; Ali, S.; Hussain, A.; Gull, M. Biomass production for bioenergy using marginal lands. Sustain. Prod. Consum. 2017, 9, 3-21. [CrossRef]

7. James, L. Theory and Identification of Marginal Land and Factors Determining Land Use Change. Master's Thesis, University of Michigan, Lansing, MI, USA, 2010. 
8. Ricardo, D. On the Principles of Political Economy and Taxation, 3rd ed.; J.M. Dent and Sons Ltd.: London, UK, 1817.

9. Hollander, J.H. The concept of marginal rent. Q. J. Econ. 1895, 9, 175-187. [CrossRef]

10. Shujiang, K.; Post, W.M.; Nichols, J.A.; Wang, D.; West, T.O.; Bandaru, V.; Izaurralde, R.C. Marginal lands: Concept, assessment and management. J. Agric. Sci. 2013, 5, 129-139. [CrossRef]

11. Schroers, J.O. Towards the Development of Marginal Land Use Depending on the Framework of Agricultural Market, Policy and Production Techniques; University of Giessen: Giessen, Germany, 2006.

12. European Environmental Agency (EEA). Marginal Land Concept. Available online: http://www.eionet. europa.eu/gemet/concept/5023 (accessed on 30 April 2018).

13. Peterson, G.M.; Galbraith, J.K. The concept of marginal land. J. Farm Econ. 1932, 14, 295-310. [CrossRef]

14. Yakubu, A.S.; Ehlers, M.H.; Harnmeijer, J. Anaerobic Digestion of Feedstock Grown on Marginal Land: Break-Even Electricity Prices. Energies 2017, 10, 21. [CrossRef]

15. Shortall, O.K. "Marginal land" for energy crops: Exploring definitions and embedded assumption. Energy Policy 2013, 62, 19-27. [CrossRef]

16. Lal, R. World crop residues production and implications of its ude as a biofuel. Environ. Int. 2005, 31, 575-584. [CrossRef]

17. Pointereau, P.; Coulon, F.; Girard, P.; Lambotte, M.; Stuczynski, T.; Sanchez Ortega, V.; Del Rio, A. Analysis of Farmland Abandonment and the Extent and Location of Agricultural Areas That Are Actually Abandoned or Are in Risk to be Abandoned, 1st ed.; Anguiano, E., Bamps, C., Terres, J.M., Eds.; OPOCE: Luxembourg, 2008; pp. 13-93.

18. Van Eupen, M.; Elbersen, B.; Mantel, S. Marginal Land. Available online: https://iiasa-spatial. maps.arcgis.com/apps/webappviewer/index.html?id=c0105c0d94c34048a1c32fba1d65a6b1 (accessed on 9 September 2018).

19. Sanchez, J.; Curt, M.D.; Fernandez, J. Approach to the potential production of giant reed in surplus saline lands of Spain. Glob. Chang. Biol. Bioenergy 2017, 9, 105-118. [CrossRef]

20. Atance, I.; Orodea, L.F.; Puente, J.F.; Garcia, L.; Gonzalez, B.; Olmedilla, S. MAGRAMA (2013): Resultados Técnico-Económicos de Cultivos Herbáceos 2011, 1st ed.; Subdirección General de Análisis, Prospectiva y Coordinación, Subsecretaria; Ministerio de Agricultura, Alimentacion y Medio Ambiente: Madrid, Spain, 2013; pp. 1-36.

21. Instituto Nacional de Estadística (INE Base). Censo Agrario. Available online: https://www.ine. es/dyngs/INEbase/es/operacion.htm?c=Estadistica_C\&cid=1254736176851\&menu=resultados\&secc= $1254736194955 \& \mathrm{idp}=1254735727106$ (accessed on 29 March 2018).

22. Instituto Nacional de Estadística (INE Base). Encuesta Sobre la Estructura de las Explotaciones Agrarias. Available online: https://www.ine.es/dyngs/INEbase/es/operacion.htm?c=Estadistica_C\& cid=1254736176854\&menu=ultiDatos\&idp=1254735727106 (accessed on 3 April 2018).

23. Ministerio de Agricultura, Pesca y Alimentación (MAPA). Anuario de Estadística 2016. Available online: https://www.mapa.gob.es/es/estadistica/temas/publicaciones/anuario-de-estadistica/2016/ default.aspx (accessed on 7 November 2018).

24. Secretaria General de Agricultura y Alimentación. Evolución de la Superficie y Producción de Cereales en España; Ministerio de Agricultura, Pesca y Alimentación: Madrid, Spain, 2016.

25. Ministerio de Agricultura, Pesca y Alimentación. Bienes y los Rendimientos Asegurables, las Condiciones Técnicas Mínimas de Cultivo, el Ámbito de Aplicación, los Periodos de Garantía, las Fechas de Suscripción y los Precios Unitarios del Seguro de Explotaciones de Cultivos Herbáceos Extensivos, Comprendido en el Trigésimo Noveno Plan de Seguros Agrarios Combinados; MAPA: Madrid, Spain, 2018; pp. 84078-84263.

26. Eiriz, G.; Orodea, L.F.; García, L.; Ramírez, G.; Simarro, J.C. MAGRAMA (2017): Resultados Técnico Económicos de Cultivos Herbáceos 2016, 1st ed.; Subdirección General de Análisis, Prospectiva y Coordinación, Subsecretaria; Ministerio de Agricultura, Alimentacion y Medio Ambiente: Madrid, Spain, 2017; pp. 1-78.

27. Ministerio de Agricultura, Pesca y Alimentación (MAPA). Hojas de Cálculo de Costes de Maquinaria. Available online: https://www.mapa.gob.es/es/ministerio/servicios/informacion/plataforma-deconocimiento-para-el-medio-rural-y-pesquero/observatorio-de-tecnologias-probadas/maquinariaagricola/hojas-calculo-maqui.aspx (accessed on 18 October 2018). 
28. Lopez, L.; Betran, J.; Ramos, A.; Lopez, H.; Lopez, P.; Bermejo, J.L.; Urbano, P.; Piñeiro, J.; Castro, J.; Blazquez, R.; et al. Guía Práctica de la Fertilización Racional de los Cultivos en España. Parte II, 1st ed.; Ministerio de Medio Ambiente, Medio Rural y Marino: Madrid, Spain, 2009; pp. 1-144.

29. Fombellida, A.; Garijo, J. Manual Para el Cumplimiento de la Condicionalidad. Cereales de Invierno, 1st ed.; Ministerio de Agricultura, Alimentacion y Medio Ambiente: Madrid, Spain, 2011; pp. 1-34.

30. Hispagua. Soils. Available online: http://hispagua.cedex.es/en/datos/suelos (accessed on 27 September 2018).

31. King, J.; Gay, A.; Sylvester-Bradley, R.; Bingham, I.; Foulkes, J.; Gregory, P.; Robinson, D. Modelling cereal root systems for water and nitrogen capture: Towards an economic optimum. Ann. Bot. 2003, 91, 383-390. [CrossRef] [PubMed]

32. Jahn, R.; Blume, H.P.; Asio, V.B.; Spaargaren, O.; Schad, P. Guidelines for Soil Description, 4th ed.; FAO: Rome, Italy, 2006; pp. 1-109.

33. Reeves, D.W. The role of soil organic matter in maintaining soil quality in continous cropping systems. Soil Till. Res. 1997, 43, 131-167. [CrossRef]

34. Lynch, J.; Spink, J.; Doyle, D.; Hackett, R.; Phelan, S.; Forristal, D.; Kildea, S.; Glynn, L.; Plunkett, M.; Wall, D.; et al. The Winter Wheat Guide, 1st ed.; Agriculture and Food Authority: Carlow, Ireland, 2016; pp. 1-40.

35. Arregui, L.M.; Maetzu, I.; Quemada, M. Estimación del drenaje y lavado de nitratos en un sistema de cultivo de cereal de invierno en condiciones de secano y clima Mediterráneo húmedo. In Estudios de la Zona no Saturada del Suelo, 1st ed.; Samper, F.J., Paz, A., Eds.; Dialnet: Madrid, Spain, 2005; Volume 7, pp. 137-143.

36. Vitosh, H.L. Wheat Fertily and Fertilization. Wheat Facts, 1st ed.; Michigan State University: Lansing, MI, USA, 1998; pp. 1-4.

37. FAO. Annex 1. Crop Salt Tolerance Data. Available online: http://www.fao.org/docrep/005/y4263e/ y4263e0e.htm (accessed on 21 April 2018).

38. Fleming, P.; Perrier, A.; Cavazza, L.; Tombesi, L.; Feddes, R.; Doorenbos, J.; Pereira, L.S.; Monteith, J.L.; Gunston, H.; Allen, R.; et al. Evapotranspiración del cultivo. In Guías Para la Determinación de los Requerimientos de Agua de los Cultivos, 1st ed.; FAO: Rome, Italy, 1990; pp. 87-156.

39. Ninyerola, M.; Pons, X.; Roure, J.M. Atlas Climático Digital de la Peninsula Ibérica. Metodología y Aplicaciones en Bioclimatologia y Geobotanica, Universidad Autonoma de Barcelona. Available online: http:/ / www.opengis.uab.es/wms/iberia/mms/index.htm (accessed on 30 September 2018).

40. Ciria, P.; Perez, P.; Maletta, E.; Carrasco, J.; Esteban, L.S. BIORAISE-CE. Available online: http:/ / bioraise. ciemat.es/BioraiseCE (accessed on 25 October 2018).

41. Villodre, J.; Castaño, S.; Sánchez, D.; Alfaro, M.; Ruiz, J.R.; Lopez, E.; Colina, A. Cartografía de Ocupación del Suelo en España. Proyecto SIOSE, 1st ed.; CNIG: Madrid, Spain, 2012; pp. 41-51, ISBN 978-84-695-6882-8.

42. Zadoks, J.C.; Chang, T.T.; Konzak, C.F. Decimal code for growth stages of cereals. Weed Res. 1974, 14, 415-421. [CrossRef]

43. Fernandez, J.; Curt, M.D. State of the art of Cynara cardunculus L. as an energy crop. In Proceedings of the 14th European Biomass Conference, Paris, France, 17-21 October 2005; Sjunnesson, L., Carrasco, J.E., Helm, P., Grassi, A., Eds.; ETA-Renewable Energies \& WIP-Renewable Energies: Paris, France, 2005; pp. $22-27$.

44. Soldatos, P. Economic aspects of bioenergy production from perennial grasses in marginal lands of South Europe. Bioenergy Res. 2015, 8, 1562-1573. [CrossRef]

45. Lloveras, J.; Cabases, M.A. Costes de producción de cultivos extensivos en secano y regadío. Vida Rural 2005, $401,38-47$.

46. Fernandez, J.; Hidalgo, M.; Monte, J.P.; Curt, M.D. Cynara cardunculus L. as a perennial crop for non-irrigated lands: Yields and applications. In Proceedings of the 4th International Congress on Artichoke, Valenzano, Italy, 17-21 October 2000; Bianco, V.V., Calabrese, N., Rubaztky, V., Eds.; ISHS (International Society for Horticultural Science). Acta Horticulturae 681: Valenzano, Italy; pp. 109-115. [CrossRef]

47. Gominho, J.; Lourenco, A.; Palma, P.; Lourenco, M.E.; Curt, M.D.; Fernandez, J.; Pereira, H. Large scale cultivation of Cynara cardunculus L. for biomass production-A case study. Ind. Crop. Prod. 2011, 33, 1-6. [CrossRef]

48. Fernando, A.L.; Boleó, S.; Barbosa, B.; Costa, J.; Duarte, M.P.; Monti, A. Perennial grass production opportunities on Marginal Mediterranean land. Bioenergy Res. 2015, 8, 1523-1537. [CrossRef]

49. Monti, A.; Cosentino, S.L. Conclusive results of the European project OPTIMA: Optimization of perennial grasses for biomass production in the Mediterranean area. Bioenergy Res. 2015, 8, 1459-1460. [CrossRef] 
50. Sanz, M.; Mosquera, F.; Sanchez, G.; Barreiro, M.; Aguado, P.L.; Sanchez, J.; Curt, M.D.; Fernandez, J. Biomass potential of triticale and rye in two different phenological stages and energy characterization. In Proceedings of the 19th European Biomass Conference, Berlin, Germany, 6-11 July 2011; Faulstich, M., Ossenbrink, H., Dallemand, J.F., Baxter, D., Grassi, A., Helm, P., Eds.; ETA Renewable Energies: Berlin, Germany, 2011; pp. 591-595.

51. Ciria, P.; Maletta, E.; Del Val, M.A.; Pérez, J.; Pérez, P.; Carrasco, J. Cultivos Herbáceos Anuales para Producción de Biomasa en España en el Marco del Proyecto Singular Estratégico On-Cultivos, 1st ed.; Ciemat: Madrid, Spain, 2015; pp. 1-116, ISBN 978-84-7834-732-2.

52. Sastre, C.M.; Maletta, E.; Gonzalez-Arechavala, Y.; Ciria, P.; Santos, A.M.; Del Val, A.; Perez, P.; Carrasco, J. Centralised electricity production from winter cereals biomass grown under central-northern Spain conditions: Global warming and energy yield assessments. Appl. Energy 2014, 114, 737-748. [CrossRef]

53. Pulighe, G.; Bonati, G.; Fabiani, S.; Barsali, T.; Lupia, F.; Vanino, S.; Nino, P.; Arca, P.; Roggero, P.P. Assessment of the Agronomic Feasibility of Bioenergy Crop Cultivation on Marginal and Polluted Land: A GIS-Based Suitability Study from the Sulcis Area, Italy. Energies 2016, 9, 18. [CrossRef]

54. Campbell, J.E.; Lobell, D.B.; Genova, R.C.; Field, C.B. The global potential of bioenergy on abandoned agriculture lands. Environ. Sci. Technol. 2008, 42, 5791-5794. [CrossRef] [PubMed]

55. INE. España en Cifras 2017 (INE Base). 2017. Available online: https:/ / www.ine.es/prodyser/espa_cifras / 2017/index.html\#38 (accessed on 7 November 2018).

56. Meyer, A.K.P.; Ehimen, E.A.; Holm-Nielsen, J.B. Future European biogas: Animal manure, straw and grass potentials for a sustainable European biogas production. Biomass Bioenergy 2018, 111, 154-164. [CrossRef]

57. Mattioli, A.; Boscaro, D.; Dalla Venezia, F.; Santacroce, F.C.; Pezzuolo, A.; Sartori, L. Biogas from residual grass: A territorial approach fos sustainable bioenergy production. Waste Biomass Valor. 2017, 8, 2747-2756. [CrossRef]

58. Nizami, A.S.; Orozco, A.; Groom, E.; Dieterich, B.; Murphy, J.D. How much gas can we get from grass? Appl. Energy 2012, 92, 783-790. [CrossRef]

59. Chiumenti, A.; Boscaro, D.; da Borso, F.; Sartori, L.; Pezzuolo, A. Biogas from fresh spring and summer grass: Effect of the harvesting period. Energies 2018, 11, 1466. [CrossRef]

60. Ciria, C.S.; Carrasco, J.; Perez, J.; Barro, R.; Ciria, P. Pure and mixed perennial biomass crops for a constraint marginal land in north-central Spain (a 6-year study). In Proceedings of the 25th European Biomass Conference \& Exhibition, Stockholm, Sweden, 12-15 June 2016; pp. 120-124. [CrossRef]

61. Glover, J.D.; Culman, S.W.; DuPont, S.T.; Broussard, W.; Young, L.; Mangan, M.E.; Mai, J.G.; Crews, T.E.; DeHaan, L.R.; Buckley, D.H.; Ferris, H.; et al. Harvested perennial grasslands provide ecological benchmarks for agricultural sustainability. Agric. Ecosyst. Environ. 2010, 137, 3-12. [CrossRef]

62. Ciria, P.; Ciria, C.S.; Maletta, E.; Perez, J.; Barro, R.; Carrasco, J.E. Varietal response of Elytrigia elongata under semiarid conditions in Spain: Establishment. In Proceedings of the 23rd European Biomass Conference and Exhibition, Vienna, Austria, 1-4 June 2015; Baxter, D., Grassi, A., Helm, P., Eds.; ETA-Florence: Vienna, Austria, 2015; pp. 139-146. [CrossRef]

(C) 2019 by the authors. Licensee MDPI, Basel, Switzerland. This article is an open access article distributed under the terms and conditions of the Creative Commons Attribution (CC BY) license (http:/ / creativecommons.org/licenses/by/4.0/). 